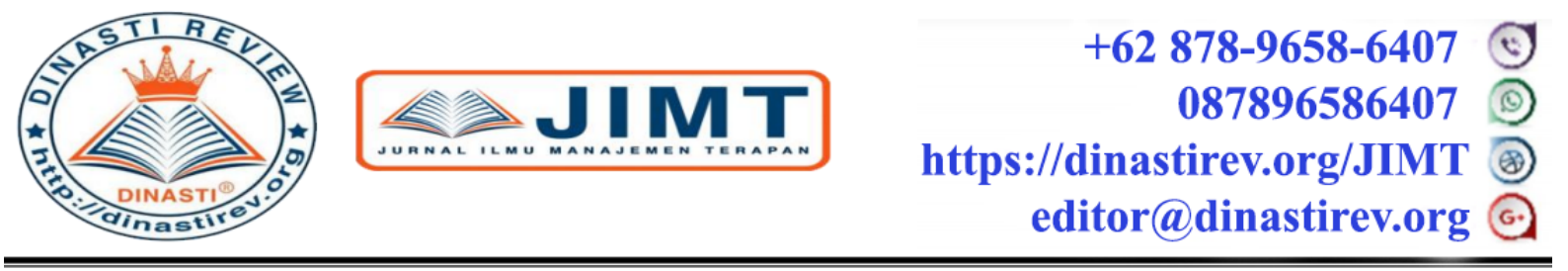

\title{
PENGARUH NILAI-NILAI INTI BPS DAN KEPUASAN KERJA TERHADAP KINERJA PEGAWAI BPS DI PROVINSI BALI
}

\section{Gede Iwan Santika}

Universitas Terbuka

\begin{tabular}{|c|l|}
\hline $\begin{array}{c}\text { ARTICLE INFORMATION } \\
\text { Received: 4 Mei } 2020 \\
\text { Revised: 15 Juni } 2020 \\
\text { Issued: 29 Juli } 2020\end{array}$ & $\begin{array}{l}\text { Abstrak: Kinerja BPS untuk dalam mewujudkan visi } \\
\text { tersebut tercermin dari kinerja setiap pegawainya. Semakin } \\
\text { efektif dan efisien karyawan dalam suatu organisasi akan } \\
\text { mencerminkan efektif dan efisiennya suatu organisasi. } \\
\text { Dalam survei Budaya Organisasi BPS, nilai-nilai inti BPS } \\
\text { di Provinsi Bali belum menunjukkan nilai yang maksimal. } \\
\text { Nilai tertinggi adalah perilaku disiplin pada nilai Integritas } \\
\text { yaitu 81,09 persen dan nilai terendah adalah perilaku adil } \\
\text { pada nilai Amanah yaitu 45,80 persen. Keadaan ini } \\
\text { menunjukkan bahwa masih adanya kesenjangan dalam } \\
\text { E-mail: }\end{array} \quad \begin{array}{l}\text { pelaksanaan nilai-nilai inti BPS yang merupakan budaya } \\
\text { organisasi di BPS. Untuk itu menarik untuk diungkap lebih } \\
\text { jauh dalam penelitian bagaimana pengaruh nilai-nilai inti } \\
\text { BPS dan kepuasan kerja terhadap kinerja pegawai BPS di } \\
\text { Provinsi Bali. Dari kajian literatur dan data didapat } \\
\text { Kesesuaian nilai-nilai suatu organisasi dengan nilai-nilai } \\
\text { yang dianut personal pegawai akan menghasilkan } \\
\text { kepuasan kerja pegawai. Semakin banyak kesesuaian nilai- } \\
\text { nilai tersebut akan semakin tinggi tingkat kepuasan } \\
\text { pegawai yang akan berimbas pada meningkatnya kinerja } \\
\text { pegawai. Level kinerja pegawai akan mencerminkan level } \\
\text { kinerja organisasi. } \\
\text { Kata Kunci: Kepuasan kerja, Kinerja Pegawai. }\end{array}$ \\
\hline
\end{tabular}

\section{PENDAHULUAN}

Badan Pusat Statistik (BPS) mengupayakan peningkatan kontribusi pada pembangunan nasional di bidang statistik guna mendukung visi reformasi birokrasi pemerintah. Upaya BPS pada penyediaan data yang berkualitas searah dengan Misi Pembangunan Nasional 2005-2025 yaitu "Mewujudkan bangsa yang berdaya saing". Visi BPS yaitu "Pelopor Data Statistik Terpercaya untuk Semua". Dalam upaya tersebut, setiap insan BPS dituntun dengan nilai-nilai inti BPS. Nilainilai inti ini adalah pondasi jati diri yang mengarahkan setiap insan BPS dalam tugas sehari-hari. Adapun nilai-nilai inti BPS yang dimaksud adalah Profesional, Integritas, dan Amanah. 
Kinerja BPS untuk dalam mewujudkan visi tersebut tercermin dari kinerja setiap pegawainya. Semakin efektif dan efisien karyawan dalam suatu organisasi akan mencerminkan efektif dan efisiennya suatu organisasi (Omolayo dan Oluwafemi (2012) dalam Inuwa, 2015). Kinerja pegawai dipengaruhi oleh beberapa faktor diantaranya adalah kepuasan kerja. Tingginya tingkat kepuasan kerja akan mendongkrak level kinerja seorang karyawan. Baroroh (2013) menyebutkan bahwa semakin tinggi tingkat kepuasan kerja seorang karyawan akan semakin tinggi kinerjanya, begitu pula sebaliknya. Kepuasan kerja yang dirasakan oleh pegawai merupakan salah satu dampak dari budaya organisasi yang baik (Wahyuniardi et al, 2018). Ogbonna dan Harris dalam Sobirin (2018) menyatakan bahwa budaya organisasi merupakan keyakinan, tata nilai serta asumsi kolektif yang diyakini oleh suatu organisasi untuk digunakan dalam interaksi dan bereaksi terhadap lingkungan.

Dalam survei Budaya Organisasi BPS, nilai-nilai inti BPS di Provinsi Bali belum menunjukkan nilai yang maksimal. Nilai tertinggi adalah perilaku disiplin pada nilai Integritas yaitu 81,09 persen dan nilai terendah adalah perilaku adil pada nilai Amanah yaitu 45,80 persen. Keadaan ini menunjukkan bahwa masih adanya kesenjangan dalam pelaksanaan nilai-nilai inti BPS yang merupakan budaya organisasi di BPS. Untuk itu menarik untuk diungkap lebih jauh dalam penelitian bagaimana pengaruh nilai-nilai inti BPS dan kepuasan kerja terhadap kinerja pegawai BPS di Provinsi Bali.

Tujuan yang ingin dicapai dalam penelitian ini adalah : 1) Menganalisis pengaruh nilainilai inti BPS secara simultan maupun parsial terhadap kepuasan kerja dan kinerja pegawai BPS di Provinsi Bali; dan 2) Menganalisis pengaruh langsung dan tidak langsung nilai-nilai inti BPS terhadap kinerja pegawai BPS di Provinsi Bali.

Diharapkan dari penelitian mendapatkan manfaat, yaitu : 1) Secara teoritis, dapat memperkuat teori yang sudah ada bahwa budaya organisasi yang tercermin pada nilai inti BPS dan kepuasan kerja berpengaruh pada kinerja pegawai; dan 2) Secara praktis, hasil penelitian ini sebagai masukan bagi Pimpinan BPS dalam upaya meningkatkan kinerja pegawai melalui penerapan nilai-nilai inti BPS sebagai budaya kerja dan kepuasan pegawai sehingga kontribusi BPS dalam pembangunan nasional dalam bidang statistik lebih optimal.

\section{KAJIAN PUSTAKA}

\section{Budaya Organisasi dan Kepuasan Kerja}

Budaya organisasi di BPS adalah nilai-nilai inti BPS yaitu profesional, integritas dan amanah. Nilai profesional terdiri dari unsur kompeten, efektif, efisien, inovatif dan sistemik. Nilai integritas terdiri dari unsur dedikasi, disiplin, konsisten, terbuka dan akuntabel. Serta nilai amanah terdiri dari unsur terpercaya, jujur, tulus dan adil.

Kepuasan kerja merupakan gambaran perasaan positif karyawan mengenai kesenangannya akan pekerjaan yang dilakukan karena mendapatkan nilai-nilai yang penting bagi karyawan itu sendiri. Hasibuan (2001) menyebutkan bahwa kepuasan kerja merupakan sikap emosional yang menggambarkan rasa senang dan suka terhadap pekerjaannya.

Penelitian Tumbelaka, et al (2016) menyebutkan bahwa budaya organisasi berpengaruh positif terhadap kepuasan kerja karyawan. Begitu pula dengan hasil penelitian Wahyuniardi, et al (2018). Berdasarkan uraian di atas disajikan hipotesis sebagai berikut : 


\section{H1 : Nilai Profesional, Integritas dan Amanah secara parsial berpengaruh signifikan terhadap Kepuasan Kerja}
H2 : Nilai Profesional, Integritas dan Amanah secara simultan berpengaruh signifikan terhadap Kepuasan Kerja

\section{Kepuasan Kerja dan Kinerja Pegawai}

Inuwa (2015) menyebutkan bahwa kinerja pegawai merupakan indikator hasil dari pekerjaan yang dilakukan oleh pegawai. Kepuasan karyawan akan meningkatkan level kinerja pribadi yang akan menggambarkan level kinerja dari perusahaan. Nuryanti (2020) menyebutkan bahwa terdapat hubungan positif antara kepuasan kerja dan kinerja seorang karyawan. Karyawan dengan tingkat kepuasan kerja yang tinggi akan menghasilkan kinerja yang tinggi pula. Berdasarkan uraian di atas disajikan hipotesis sebagai berikut :

\section{H3 : Kepuasan Kerja berpengaruh signifikan terhadap Kinerja Pegawai}

\section{Budaya Organisasi dan Kinerja Pegawai}

Barry Posner dalam Sobirin (2018) mengatakan bahwa jika ada kecocokan nilai-nilai organisasi dengan nilai-nilai personal pegawai akan mengahasilkan sikap positif karyawan tersebut yang berimbas pada kinerjanya. Edy (2019) dalam penelitiannya menyebutkan bahwa budaya organisasi berpengaruh signifikan terhadap kinerja pegawai. Berdasarkan uraian di atas disajikan hipotesis sebagai berikut :

H4 : Nilai Profesional, Integritas dan Amanah secara parsial berpengaruh signifikan terhadap Kinerja Pegawai

H5 : Nilai Profesional, Integritas dan Amanah secara simultan berpengaruh signifikan terhadap Kinerja Pegawai

Dalam penelitian ini digunakan lima variabel yaitu Nilai Profesional (X1), Nilai Integritas (X2), Nilai Amanah (X3), dan Kepuasan Kerja (Y) sebagai variabel bebas, serta Kinerja Pegawai (Z) sebagai variabel tidak bebas. Keterkaitan variabel-variabel tersebut dijelaskan dalam kerangka pemikiran sebagai berikut:

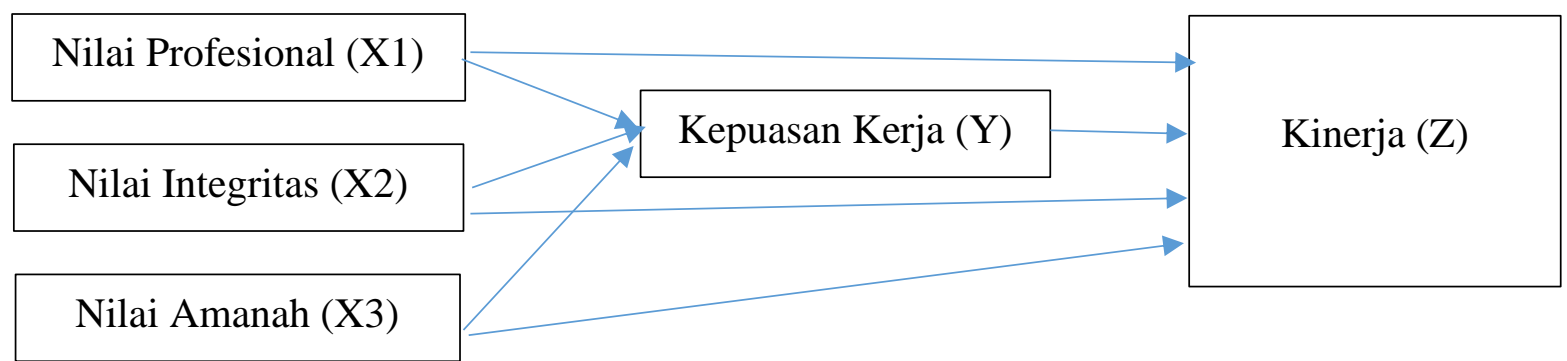

Gambar 1. Kerangka berpikir

\section{METODE PENELITIAN}

Penelitian ini merupakan penelitian Testing Hypothesis melalui pendekatan kuantitatif. Pengumpulan data pada penelitian ini dilakukan secara Cross Sectional dengan cara menyebarkan 
kuesioner kepada sampel terpilih melalui Google Form. Sampel merupakan pegawai BPS di Provinsi Bali.

Pegawai BPS di Provinsi Bali berjumlah 238 orang tersebar di sepuluh Kantor BPS Provinsi serta Kabupaten/Kota. Sampel akan dipilih secara acak berlapis. Pegawai BPS di Provinsi Bali dikelompokkan dalam 3 strata yaitu Struktural, Fungsional Tertentu dan Fungsional Umum.

Metode analisis data yang diperoleh dari hasil pengumpulan data menggunakan aplikasi SPSS 23. Terlebih dahulu akan dilakukan uji Validitas dan Reliabilitas kuesioner yang digunakan. Setelah dilakukan pengujian asumsi-asumsi, dilakukan pengujian dengan menggunakan analisis regresi linier berganda yang dilanjutkan dengan analisis jalur.

\section{KESIMPULAN DAN DISKUSI}

Kesesuaian nilai-nilai suatu organisasi dengan nilai-nilai yang dianut personal pegawai akan menghasilkan kepuasan kerja pegawai. Semakin banyak kesesuaian nilai-nilai tersebut akan semakin tinggi tingkat kepuasan pegawai yang akan berimbas pada meningkatnya kinerja pegawai. Level kinerja pegawai akan mencerminkan level kinerja organisasi.

Pada penelitian ini nantinya diharapkan mampu memberikan informasi bagi Pimpinan BPS terkait budaya organisasi yang tercermin dalam nilai-nilai inti BPS dalam rangka peningkatan kontribusi BPS pada pembangunan nasional di bidang statistik.

\section{DAFTAR PUSTAKA}

Ali, H., \& Limakrisna, N. (2013) Metodologi Penelitian (Petunjuk Praktis untuk Pemecahan Masalah Bisnis, Penyusunan Skripsi, Tesis, dan Disertasi). Yogyakarta : Deepublish.

Baroroh, S. (2013). Hubungan Antara Kepuasan Kerja Dengan Kinerja Karyawan, Fakultas Psikologi Universitas Muhammadiyah Surakarta. Diambil 24 April 2020 di http://eprints.ums.ac.id/26721/11/02._NASKAH_PUBLIKASI. pdf

BPS. (2015). Reformasi Birokrasi Badan Pusat Statistik Roadmap 2015-2019.

BPS. (2018). Buku Laporan Survei Provinsi Bali Change Management Program.

Edy, S. (2019). Pengaruh Kepemimpinan, Kemampuan Kerja dan Budaya Organisasi Terhadap Kinerja Pegawai Badan Keuangan Daerah Kabupaten Probolinggo. Program Pasca Sarjana Universitas Terbuka Jakarta. Diambil $27 \quad$ April 2020 di http://repository.ut.ac.id/8702/1/43872

Hasibuan, M. SP. (2001). Manajemen Sumber Daya Manusia, Edisi Revisi : Bumi Aksara

Inuwa, M. (2015). The Impact of Job Satisfaction, Job Attitude and Equity on Employee Performance. The International Journal Of Business \& Management, 3, 288-293. Diambil dari : https://www.researchgate.net/publication/321966670

Nuryanti. (2020). Kepuasan Kerja Dan Komitmen Organisasional Berpengaruh Terhadap Kinerja Karyawan. E-Jurnal Manajemen, Vol. 9, No. 3, 2020 : 926-947. Diambil 27 April 2020 dari https://doi.org/10.24843/EJMUNUD.2020.v09.i03.p06 
Sobirin, A. (2018). Perilaku Organisasi. Tangerang Selatan : Universitas Terbuka.

Tumbaleka, S.S.X., Alhabsji, T., \& Nimran, U. (2016). Pengaruh Budaya Organisasi Terhadap Kepuasan Kerja, Komitmen Organisasional Dan Intention To Leave (Studi pada Karyawan PT.Bitung Mina Utama). Jurnal Bisnis dan Manajemen, 3(1), 94-108. Diambil 26 April 2020 di http://jurnal.unmer.ac.id/index.php/jbm/article/download/78/19

Wahyuniardi, R., Nurjaman, S. \& Ramadhan, M.R. (2018). Pengaruh Budaya Organisasi dan Lingkungan Kerja terhadap Kepuasan Kerja dan Kinerja Karyawan. Jurnal Optimasi Sistem Industri, 17 (2), 143-151, doi : 10.25077/josi.v17.n2.p143-151.2018. Diambil 26 April 2020 di http://josi.ft.unand.ac.id/index.php/josi/article/view/240/186 